\title{
超選択的動注と放射線の同時併用療法
}

\author{
本間 明宏・鈴木 章之・犬山 征夫・福田＼cjkstart諭

\section{Superselective Arterial Infusion and Concomitant Radiotherapy}

\author{
Akihiro Homma, Fumiyuki Suzuki, Yukio Inuyama and Satoshi Fukuda \\ (Hokkaido University)
}

Superselective arterial infusion for patients with advanced head and neck cancer has been increasingly applied in Japan. We analyzed our experiences and evaluated the efficacy and safety of this treatment.

Patients and methods: Through October 1999 to March 2002, 29 patients, ranging in age between 33 and 71 years (median 52 years), received superselective intra-arterial infusion therapy of cisplatin (100$120 \mathrm{mg} / \mathrm{m}^{2} /$ week) with simultaneous intravenous infusion of thiosulfate for neutralizing cisplatin toxicity, and conventional concomitant extrabeam radiotherapy ( $65 \mathrm{~Gy} / 26 \mathrm{f} / 6.5$ weeks). Four patients were diagnosed with stage III and 25 with stage IV. Thirteen patients were considered contraindicated for surgery, and the other 16 patients rejected radical surgery. Primary tumor sites included paranasal sinus (11 patients), hypopharynx (7), oropharynx (6), oral cavity (4), and parotid gland (1).

Results: During the median follow-up period of 20 months, there was no apparent recurrence in 14 $(48.3 \%)$ of 29 patients. Eleven $(37.9 \%)$ patients died of disease, and three $(10.3 \%)$ were alive with disease. In twenty-one patients $(72.4 \%)$ the primary lesions were well-controlled. Acute toxic effects were moderate, and severe toxic events occurred in four cases, namely, MRSA pneumonia, sepsis, tetraplasia, and osteoradionecrosis.

Conclusions: We confirmed the effectiveness and safety of superselective arterial infusion and concomitant radiotherapy. Furthermore, we must establish the optimal procedures and schedule, as well as the indications for this treatment. This treatment protocol may improve the prognosis of patients with unresectable disease and patients rejecting surgical treatment. Further study in this particular area is needed.

Key words : superselective, arterial infusion, radiotherapy, head and neck cancer

\section{はじめに}

頭頸部癌に対する動注化学療法の歴史は古く, 1950 年 に Klopp ら ${ }^{1)}$ が nitrogen mustard を動注したのが最初の 報告である. $1960 １ 970$ 年代には三者併用療法として 広く日本で行われた。 しかし，その方法は浅側頭動脈か ら逆行性にカテーテルを挿入して色素で染まる領域を参 考にして位置を決定し留置する方法で，カテーテルの位 置の移動, 閉塞などのトラブルや効果にばらつきがあり, 計画した動注を行えない場合も少なくなかった。 その後,
大きな進歩がなく，再建手術の進歩に伴いあまり注目さ れなくなったが，さまざまな工夫により進歩を遂げ，近 年再び脚光を浴びるようになった。

それは interventional radiology の進歩により, 比較的安 全に選択的に腫瘍の栄養血管にカテーテルを挿入するこ とが可能となったことが最大の要因である.そして Robbinsら²がSeldinger法により大量のシスプラチンを超 選択的に動注し，そのシスプラチンをチオ硫酸ナトリウ ムにて中和することにより週 1 回の動注が安全に行える 
ことを明らかにし，さらに照射と併用し，進行癌におい て $90 \%$ を超える CR 率を報告した ${ }^{3)}$. その結果により再 び注目されるようになり，本邦では横山ら ${ }^{4)}$ が同様に高 い効果, 安全性を報告し, 日本でも広まりつつある.

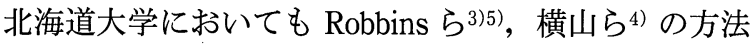
に準じて超選択的動注療法を集学的治療のなかに取り入 れてきた。本論文では超選択的動注と放射線の同時併用 について自験例を検討し，その方法，適応について述べ てみたい.

\section{対象}

進行癌新鮮例で遠隔転移のないもの，重篤な合併症の ない 60 歳以下の症例で, 原発あるいは頸部リンパ節転移 のいずれかが臨床的に手術不能と考えられた例，あるい は手術拒否例を対象としている。しかし動注療法の安全 性が確認されたため, 全身状態が良好であれば 60 歳以上 でも対象とする場合がある。

今回解析した対象は, 北海道大学にて 1999 年 10 月か ら 2002 年 3 月までに初診し, 超選択的動注化学療法と放 射線療法の同時併用を行った頭頸部原発進行癌29例であ る. 性別は男性が 23 例, 女性が 6 例で，年齢は $33 \sim 71$ 歳, 中央值は 52 歳, 平均は 52.2 歳である. 症例の内訳 は表 1 の通りであるが，T3 が 12 例，T4 が 17 例と原発 の進行した例が多く，ステージ III が 4 例，IV が 25 例で あった。臨床的に手術不能と考えられたのが 13 例 (44.8 $\%)$ ，手術拒否例が 16 例（55.2\%）であった。病理組織 は扁平上皮癌が 28 例, 腺様囊胞癌が 1 例であった. 原発 部位は鼻副鼻腔が 11 例, 下咽頭 7 例, 中咽頭 6 例, 口腔 4 例, 耳下腺 1 例であった。

\section{方法}

当科の動注は Robbins $ら^{335)}$ ，横山ら ${ }^{4)}$ の方法にほぼ準

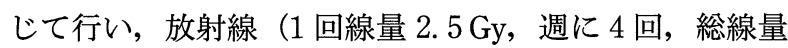
$65 \mathrm{~Gy})$ と，週に 1 回，計 4 回ほどの動注を同時併用して いる.ただし下咽頭の場合は照射野が広いので 1 回線量

表 1 対象

\begin{tabular}{crrrrrrr}
\hline \hline $\mathrm{T} \backslash \mathrm{N}$ & 0 & 1 & $2 \mathrm{a}$ & $2 \mathrm{~b}$ & $2 \mathrm{c}$ & 3 & 計 \\
\hline $\mathrm{T} 3$ & 3 & 1 & & 4 & 3 & 1 & 12 \\
$\mathrm{~T} 4$ & 10 & 1 & & 1 & 3 & 2 & 17 \\
\hline 計 & 13 & 2 & & 5 & 6 & 3 & 29
\end{tabular}

$2.0 \mathrm{~Gy}$, 週に 4 回, 総線量 $66 \mathrm{~Gy}$ とし, 舌の 2 例につい ては外照射 $40 \sim 50 \mathrm{~Gy}$ と動注のあと, 高線量率イリジウ ム線源治療を行った，当院では，以前から施設，スタッ フの事情から頭頸部癌に対する照射は 1 回線量 $2.5 \mathrm{~Gy}$, 週 4 回を標準治療としており, 今回も同様の当院で以前 から行っている方法で行った。

動注は, Seldinger 法により大腿動脈からカテーテル導 入シースを動脈内に留置し，そこから $5 \mathrm{~F}$ の親カテーテ ルを外頸動脈まで進め外頸動脈造影を行い，おおよその 血行動態をつかみ，そこからマイクロカテーテルを親カ テーテルに挿入して腫瘍の栄養血管となっている可能性 のある外頸動脈の枝に挿入していく. 血管の太さ, 角度, 分岐の仕方などから抗がん剂を投与する適切なカテーテ ルの位置を決める. 1 回に投与するシスプラチンの量は $100 \sim 120 \mathrm{mg} / \mathrm{m}^{2}$ で，投与直前に横山ら ${ }^{4)}$ の方法に準じ てメイロンを加え $\mathrm{pH}$ の調整を行った。主に原発巣に対 して行い，主要な栄養血管に対して選択的にカテーテル を挿入し動注した. $3 \mathrm{~cm}$ 以上のリンパ節転移については リンパ節に対しても動注したが，リンパ節が治療後残存 したもの, 残存が疑われる症例については後に頸部郭清 を行った。

シスプラチンの投与と同時にチオ硫酸ナトリウム 20 $24 \mathrm{~g}$ を中心静脈ラインから点滴静注した。動注当日は, 利尿剂を併用し約 $10 \ell$ の補液を行い, 腎障害の予防に努 めた. また，悪心・嘔吐予防のため $5 \mathrm{HT} 3$ 拮抗薬を投与 した.

\section{結 果}

動注は 29 例に対して 97 回行った. 動注回数の平均 3.3 回（1 回〜 6 回）であった. 現在までの生存例の平均観 察期間は 1 年 8 カ月（9カ月〜 3 年 3 カ月） であるが, 非 担癌生存 14 例 $(48.3 \%)$, 原病死 11 例 $(37.9 \%)$, 担癌 生存 3 例 $(10.3 \%)$, 他病死 1 例（3.4\%）であった（表 2). Kaplan-Meier 法による 2 年生存率は $42.9 \%$ であった. 動注と照射によって原発巣が制御されたのは 21 例 (72.4\%) であった. 再発した 8 例のうち 3 例に救済手術 を行ったが全例に再び原発巣の再発をきたした．頸部り ンパ節転移に対しても動注を行っているが，N（+）例 16 例のうちで動注と照射によって制御されたのが 8 例 （50\%）あった. 8 例の転移リンパ節は再発あるいは残存 し，頸部郭清を行った 3 例は制御された．残りの 5 例は 原発巣再発，あるいは遠隔転移を伴っており，再発した 
表 2 結果

\begin{tabular}{lll}
\hline \hline 非担癌生存 & & $14(48.3 \%)$ \\
原病死 & 3 & $11(37.9 \%)$ \\
原発 & 3 & \\
原発十頸部 & 2 & \\
遠隔 & 1 & \\
頸部 (健側) & 2 & \\
$\quad$ 頸部+遠隔 & & \\
担癌生存 & 2 & \\
原発 & 1 & \\
遠隔 & $10.3 \%)$ \\
他病死 & & $1(3.4 \%)$
\end{tabular}

表 3 部位別局所再発率

\begin{tabular}{ccc}
\hline \hline 部位 & 症例数 & 残存 or 再発 $(\%)$ \\
\hline 口腔 & 4 & $1(25 \%)$ \\
中咽頭 & 6 & $1(16.7 \%)$ \\
下咽頭 & 7 & $3(42.9 \%)$ \\
副鼻腔 & 11 & $3(27.3 \%)$ \\
耳下腺 & 1 & 0
\end{tabular}

転移リンパ節の治療は行えなかった．初診時 N0 の 1 例 は，多発の頸部転移と遠隔転移がほぼ同時に出現し，制 御できなかった。

原発部位別にみると下咽頭は 7 例中 3 例 $(42.9 \%)$ に 原発巣の残存あるいは再発をきたした。口腔では 4 例中 1例 $(25 \%)$ ，鼻副鼻腔では 11 例中 3 例 $(27.3 \%)$ ，中咽 頭 6 例中 1 例に再発をきたしたが，耳下腺 1 例の原発巣 は制御された（表 3)。

動注と照射によって原発巣が制御できなかった 8 例を 具体的に検討する（表 4）と，栄養血管の閉塞のため，理 想的な動注が行えなかった例 (1 例)，種々の事情により
照射の途中（後半）から動注を行った例（2 例)，副作用 などで治療スケジュールが予定通り行えなかった例（3 例), 治療中に肺転移が出現し急激に悪化し治療を中止せ ざるを得なかったのが 1 例と, 8 例中 7 例は治療が予定 通りに行えなかったものであった。

Grade III以上の有害事象を挙げると白血球減少が 11 例 (37. 9\%)，粘膜炎 12 例 (41. 4\%)，血色素減少 1 例 (3.4 $\%)$, 発熱 3 例 $(10.3 \%)$, 脱毛 1 例 $(3.4 \%)$ ，皮膚炎 2 例 (6.9\%) で，grade IV は粘膜炎，皮膚炎それぞれ 1 例 のみであった（表 5)。また，経過中 MRSA 肺炎，菌血 症となったのがそれぞれ 1 例ずつ，動注により四肢麻痺 となったのが 1 例あり，以上の 3 例は合併症のため治療 を中断し， 3 例とも後に局所再発をきたした。

四肢麻痺となった例は, 下咽頭の T4N3 で 4 回目の動 注時にそれまで動注していた上甲状腺動脈が狭小化した ため, 左の甲状頸幹から下甲状腺動脈まで選択的にカ テーテルを進め，動注した．そのときには特に症状もな く終了したが，その日の夜に動こうとしても下肢が動か ないことに本人が気がついた。両下肢の麻疩, 両上肢の 軽度の麻痺があり, MRI にて前脊髄動脈の還流域に高信 号が認められ，脊髄梗塞もしくは drug induced myelopathy による前脊髄動脈症候群と考えられ, 大量ステロイ ド，高圧酸素療法を行った。しかし，上肢の障害は回復 したが, 両下肢の麻痺は残存した. また, 上顎洞の $\mathrm{T} 4 \mathrm{~N} 2 \mathrm{~b}$ 例で治療の 2 年後に下顎骨壊死をきたしたのが 1 例あっ た。これはもともと口腔衛生状態が悪かったのに加え, 下顎骨に浸潤するリンパ節転移があり,下顎骨にも $65 \mathrm{~Gy}$ の照射を行わざるを得なかった例であった，現在，保存 的に抗生剤投与で経過観察中である。 それ以外では上顎 洞原発の 3 例に，治療後閉塞性副鼻腔炎が出現した。 自 然口が閉鎖したことが原因と考えられ，1 例は内視鏡的

表 4 局所再発例の内容

\begin{tabular}{|c|c|c|c|c|}
\hline 症例 & 年齢 & 部位 & $\mathrm{TN}$ & コメント \\
\hline 1 & 46 & 篩骨洞 & T4N0 & 主栄養血管の顎動脈が 2 回目から閉塞 \\
\hline 2 & 46 & 口腔（硬口蓋） & T4N0 & 途中から動注併用（2 回） \\
\hline 3 & 66 & 中咽頭 & $\mathrm{T} 4 \mathrm{~N} 2 \mathrm{c}$ & 途中から動注併用（3 回） \\
\hline 4 & 60 & 上顎洞 & T3N0 & 治療中菌血症となり 1力月治療中断 \\
\hline 5 & 55 & 上顎洞 & T3N1 & 治療中肺炎となり 1カ月治療中断 \\
\hline 6 & 64 & 下咽頭 & T4N3 & 動注後両下肢麻痺 $\rightarrow$ 治療中止 \\
\hline 7 & 50 & 下咽頭 & T4N3 & 治療途中に肺転移出現, 悪化 $\rightarrow$ 治療中止 \\
\hline 8 & 62 & 下咽頭 & $\mathrm{T} 3 \mathrm{~N} 2 \mathrm{c}$ & 予定通りの治療を行った \\
\hline
\end{tabular}


表 5 Grade III 以上の有害事象

\begin{tabular}{lccc}
\hline \hline & 計 & Grade III & Grade IV \\
\hline 白血球減少 & $11(37.9 \%)$ & 11 & \\
粘膜炎 & $12(41.4 \%)$ & 11 & 1 \\
血色素減少 & $1(3.4 \%)$ & 1 & \\
発熱 & $3(10.3 \%)$ & 3 & \\
脱毛 & $1(3.4 \%)$ & 1 & \\
皮膚炎 & $2(6.9 \%)$ & 1 & 1
\end{tabular}

に開大した。

覀心, 嘔吐は個人差はあるものの, 多くの場合は軽度 ですべて Grade II 以下であった。 また，治療前の腎機能 が正常な例に動注を行っているが悪化した例はなかっ た. 粘膜炎, 覀心にて経口摂取が一時的に不能となり, 中心静脈栄養を行う例が多くを占めた。

\section{考察}

日本では，超選択的動注療法は以前から報告されてい

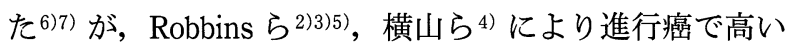
$\mathrm{CR}$ 率が報告され急速に広まってきている. しかし, 具体 的な方法となると現在でも施設により異なり，必ずしも Robbinsらの原法5)通りには行われていないのが現状であ る.まず, 投与薬剤はシスプラチンを中心とする施設が多 (4)5)8) が，その量は $30 \sim 40 \mathrm{mg} / \mathrm{m}^{2}$ 7) から $300 \mathrm{mg} / \mathrm{m}^{2}$ ) と幅が大きく, チ才硫酸ナトリウムで中和する施設が 多いが行っていない施設もあり ${ }^{677)}$, 投与回数も 1 回の み(6)799) 功週に 1 回, $3 \sim 6$ 回 ${ }^{4)}$ 行う施設もある. また, カルボプラチンの報告610) も散見され, 新しい化学療法 剤であるドセタキセルを併用する場合11) もあれば，ドセ タキセルを中心に使う施設12) むある。 それは, 動注を一 連の集学的治療のなかでどういった役割を期待して行う かによっても異なるであろう．動注を術前の induction chemotherapy として行う方法もあり, 当科でも症例を選
択して行っているが，今回は照射との同時併用で根治治 療として行うことに絞って述べたい。

また，治療効果に大きな差を及ぼす因子と思われる治 療スケジュールや，実際の投与血管の選択，カテーテル の位置, 投与速度についてもあまり議論されていないの が現状である. Robbins ら ${ }^{3)}$ が $90 \%$ を超える CR 率が得 られる治療であることを報告しており, 当科ではこの方 法を基本として高い奏功率を落とすことなく副作用の軽 減, 遠隔転移を減少させるための工夫, そして現実的な 問題として動注の回数を減らす方向で工夫していきたい と考えている.

まず治療スケジュール（図 1）であるが，当科ではシ スプラチンを $100 \mathrm{mg} / \mathrm{m}^{2}$ を週に 1 回動注するところから スタートした．複数の血管からの動注が必要な場合には 総量 $120 \mathrm{mg} / \mathrm{m}^{2}$ 投与する場合があるものの, 十分な効果 が得られたため, dose escalation は行わなかった。つま り腫瘍の栄養血管に選択的にカテーテルを挿入すること ができれば, シスプラチンの 1 回投与量は $100 \sim 120 \mathrm{mg} /$ $\mathrm{m}^{2}$ で十分と考えている.

また, 週に 1 回, 計 4 回の動注を基本としているが, 十分な効果が得られた場合は副作用が軽くても 3 回で動 注は終了とする場合もある. 5 回以上行ったのは治療経 験があまりなかった初期の 2 症例のみで, その後の症例 はすべて 4 回以下である。 また動注は, 放射線治療と同 時に始めた方が放射線治療後半から始めるよりも効果は 高い印象がある。

次にチオ硫酸ナトリウム（STS）は副作用の軽減に大 きな役割を果たしており, STSの併用により, 通常の全 身投与より多いシスプラチンの投与が週に 1 回可能と なっている. Robbins ら 2)3)5) は, シスプラチンと同時に 投与を始め, 動注終了後にも投与しており, われわれも それに準じて行っている. ただ血管造影, 動注を行って いる間はSTSがすでに投与したシスプラチンを中和する 量より多く入らないようタイミングを注意している. 動

\section{放射線}

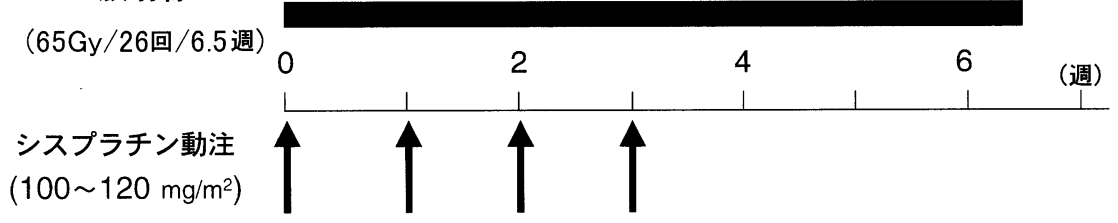

図 1 治療スケジュール 
注がすべて終了した後にSTSを投与開始している施設も あるようだが，当科の方法で抗腫湯効果が悪いときが あったという印象はなく, また, 腎機能の良い例に対し て動注療法を行っているが, 腎機能の悪化した例はなく, 悪心・嘔吐もすべて Grade II 以下で臨床上は十分満足で きる中和がなされていると考えている.

併用薬剤としてドセタキセルもときに使用する場合が あるが, 腫瘍縮小効果は早くでるものの粘膜炎がシスプ ラチン単独に比べ早期から出現し, より重症となる印象 がある. その結果は, まだ症例数が少なく解析はできな いが, 全身倦怠感がシスプラチン単独よりも強く出現し, また粘膜炎が遷延するようである.

実際の手技では, カテーテルの操作はすべて血管造影 医が行うが, 常に耳鼻咽喉科・頭頸部外科医が立会い, 相談しながら行っている. そして, 最終的な投与血管, カテーテルの位置, 投与薬剤の選択, 量, 速度はすべて われわれが決定している.

投与血管はまず外頸動脈造影を行い，栄養血管の候補 を絞り, その血管に選択的にカテーテルを挿入し, 栄養 血管であることを確認し, 腫瘍とは関係のない分枝は可 能な限りはずすようにしている，卓越した血管造影医の 技術により, かなり末梢までカテーテルの捜入は可能で あるが, 細い血管から動注すると, 次の動注のときに閉 塞していることがあるため, 複数回の動注を考慮し, あ まり末梢までは入れず，細い枝には入れないようにして いる. しかし, 最終回の動注の場合は, その血管が閉塞 してもあまり問題はないので，より選択的に挿入し，細 い枝にも可能なら選択的に挿入する. Robbins ら ${ }^{5)}$ は外 頸動脈から分岐した血管 (上甲状腺動脈, 舌動脈, 顔面 動脈など）の起始部より末梢にはカテーテルを進めない と述べているが，当科ではさらに末梢まで進めることが 多い. しかし，上述のように，あまり末梢の細い血管ま でカテーテルを進めると, 次の動注の際, 閉塞してしま い理想的な動注ができなくなる場合があるので，そのさ じ加減は難しく, 経験に基づくところが多い.

投与速度については, “逆流があるかないか”の速度に している，それは，血管内に血液がなく抗がん剤のみが 流れる状態,つまり腫瘍組織が抗がん剂で満たされた状 態が理想という理論に基づく5). そのため, 太い血管, 例 えば顎動脈本幹であれば $0.6 \mathrm{cc} /$ 秒のこともあるし, 細い 血管であれば $0.1 \mathrm{cc} /$ 秒以下の場合もある.

超選択的動注は，卓越した技術を持ち，われわれには
ない知識と経験を持つ血管造影医の協力がなければ成り 立たないが, カテーテルの位置, 投与薬剤の選択, 量, 速度は効果のみならず，副作用の出現にも大きな因子で あり, 解剖・機能, 頭頸部腫瘍について熟知した耳鼻咽 喉科・頭頸部外科医も積極的にかかわることが重要であ る. そして, 手術と同様, 両者が多くの経験を重㸚, そ れを共有することにより，手技は向上していくものと考 えている.

有害事象として，もともと全身状態の良い例を対象と しているが, 全身的な重篤な副作用は, 1 回の動注で菌 血症となった例，MRSA 肺炎となった例があったが，そ れ以外の症例は許容範囲のものであった。脳血管障害は 1 例も経験していない. 最も多く経験する副作用はやは り粘膜炎, Grade II 程度の悪心である. 粘膜炎は, ドセ タキセル $10 \mathrm{mg} / \mathrm{m}^{2}$ の点滴静注と照射の併用と比べると, やや強い程度と考えている. しかし, 照射終了後の粘膜 炎の回復は遅い印象がある. また, 悪心は個人差はある ものの, 通常のシスプラチンの全身投与よりも明らかに 軽度で許容範囲のものと考えるが，毎週行うため患者に とっては快いものではない.

また，下甲状腺動脈からの動注で四肢麻痺が 1 例に出 現したが, 下甲状腺動脈からの動注が必要な場合はあり, その場合はできるだけ末梢までカテーテルを挿入し, 逆 流のない速度で投与している，われわれが検索し得た範 囲では過去に動注で脊䯣損傷の報告はないが，血管解剖 としては甲状頸幹と前脊髄動脈は交通があり ${ }^{13)}$, 動注の 際には十分な注意が必要である.

原発巣が再発した例が 7 例あったが，そのうちの 5 例 についてはさまざまな理由で予定の治療が行えなかった 症例である. そのため, 現在はさらにシスプラチンの量 を増やしたり, 薬剤を追加したりするよりも, 副作用を 少なくして完遂率を向上させることが最も重要と考えて いる.

われわれは遠隔転移のない局所進行癌で手術不能例, 手術拒否例を適応としており，それほど進行していない 症例に適応を広げるには慎重である。それは，この治療 が初めて報告されたのが 1994 年で，まだ 10 年も経って おらず長期的な合併症が未知なためである。従来の確立 された放射線, 手術で一定の治療成績が得られている症 例に対して行うのには, さらなる症例の積み重ね, 経過 観察期間が必要と考えている.

そして, 近年進歩している全身化学療法と放射線の同 
時併用も手術不能例でもある程度の成績が得られるよう

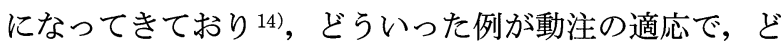
らいった例が全身化学療法の適応かの選択に苦慮するよ らになってきた。非常に原発巣が大きい場合，多発のあ るいは大きな頸部リンパ節を有する症例は遠隔転移の可 能性が高く, 全身化学療法の必要性を感じており，これ からの検討課題である. 秋定ら ${ }^{12)}$ は，ドセタキセルの動 注とシスプラチン，5FU の全身化学療法と放射線の同時 併用を行っているが，こういった全身化学療法を取り入 れたアプローチもこれから検討する必要があると考えて いる.

最後に, 超選択的動注療法は手術不能な進行癌でも治 癒に導ける可能性のある治療であり, 副作用も許容範囲 のものであることが確認された。しかし，まだ新しい治 療で晚期の副作用は未知であること，ときに重篤な合併 症の可能性が出現する可能性もあることを念頭に適応を 考える必要がある，そして，さらに症例を蓄積していく ことにより頭頸部癌治療のなかで一定の役割を担うよう になるものと期待される.

\section{まとめ}

1) 北海道大学において超選択的動注と照射の同時併 用を行った 29 例について検討した.

2 ) 対象はステージ III が 4 例, IV が 25 例で, 臨床的 に手術不能と考えられたのが 13 例 (44.8\%), 手術拒否例 が 16 例 (55.2\%) であった。

3 ) 動注は 29 例に対して 97 回行った. 動注回数は平 均 3.3 回であった. 現在までの治療結果は非担癌生存 14 例 (48. 3\%), 原病死 11 例 (37.9\%), 担癌生存 3 例 (10.3 $\%$ ), 他病死 1 例 (3.4\%) であり, Kaplan-Meier 法によ る 2 年生存率は $42.9 \%$ であった。

4 ) 動注と照射によって原発巣が制御されたのは 21 例 (72. $4 \%)$ であった.

5 ) 有害事象は, Grade III 以上の頻度の高いものは白 血球減少が 11 例 (37.9\%), 粘膜炎 12 例 $(41.3 \%)$ で, Grade IV は粘膜炎，皮膚炎それぞれ 1 例のみであった。 ま た，経過中 MRSA 肺炎，菌血症，四肢麻痺となったのが それぞれ 1 例あり，治療 2 年後に下顎骨壊死をきたした のが 1 例あった。

6）超選択的動注療法と照射の同時併用は手術不能例 も含めた進行癌においても高い局所制御率が得られる治 療であることが確認された。
本論文の要旨は第 64 回耳鼻咽喉科臨床学会（平成 14 年 6 月 29 日，大阪）にて口演した。

\section{参考文献}

1) Klopp CT, Alford TC, Bateman J, et al. : Fractionated intraarterial cancer chemotherapy with methyl bis amine hydrochioride; a pleliminary report. Ann Surg $132: 811 \sim 832,1950$.

2) Robbins KT, Storniolo AM, Kerber C, et al. : Rapid superselective high-dose cisplatin infusion for advanced head and neck malignancies. Head Neck $14: 364 \sim$ 371, 1992.

3) Robbins KT, Vicario D, Seagren S, et al. : A targeted supradose cisplatin chemoradiation protocol for advanced head and neck cancer. Am J Surg 168: $419 \sim 422 ， 1994$.

4）横山純吉, 志賀清人, 西條 茂, 他：二経路投与法による 超選択的動注療法. 頭頸部腫瘍 $24: 18 \sim 24,1998$.

5) Kerber CW, Wong WH, Howell SB, et al. : An organ-preserving selective arterial chemotherapy strategy for head and neck cancer. AJNR Am J Neuroradiol 19 : $935 \sim 941,1998$.

6) Imai S, Kajihara $Y$, Munemori O, et al. : Superselective cisplatin (CDDP)-carboplatin (CBDCA) combined infusion for head and neck cancers. Eur J Radiol $21: 94 \sim 99,1995$.

7) Hirai $T$, Korogi $Y$, Hamatake S, et al. : Stages III and IV squamous cell carcinoma of the mouth: three-year experience with superselective intraarterial chemotherapy using cisplatin prior to definitive treatment. Cardiovasc Intervent Radiol 22:201 205, 1999.

8）吉崎智一，志賀英明，真田順一郎，他：超選択的動注化学 療法による下咽頭喉頭癌治療. 日気食会報 $52: 400 \sim 408$, 2001.

9）吉田知之, 市村影英, 武藤功太郎, 他 : 頭頸部がんに対す る大量選択的動注療法による neoadjuvant chemotherapy の 検討。頭頸部腫瘍 $28: 376,2002$.

10) Fuwa N, Ito $Y$, Matsumoto A, et al. : A combination therapy of continuous superselective intraarterial carboplatin infusion and radiation therapy for locally advanced head and neck carcinoma; phase I study. Cancer $89: 2099 \sim 2105 ， 2000$.

11）横山純吉：動注療法の位置漬付けと展望. 頭頸部癌. 癌と 化学療法 $29: 169 \sim 175,2002$

12）秋定 健, 原田 保, 竹本玩司, 他：Docetaxel の超選択的 動注が有効であった進行下咽頭癌の 1 例. 癌と化学療法 29: $323 \sim 328,2002$.

13）宮坂和男：春椎・春髄の血管. 脳・脊髄血管造影マニュア ル（宮坂和男編） $147 \sim 166$ 頁，南江堂，東京， 1997.

14) Merlano M, Benasso M, Corvo R, et al. : Five-year update of a randomized trial of alternating radiotherapy and chemotherapy compared with radiotherapy alone in treatment of unresectable squamous cell carcinoma of the head and neck. J Natl Cancer Inst $88: 583 \sim 589,1996$.

原稿受付：平成14年11月18日 原稿採択 : 平成15年 1 月 22 日 別刷請求先：本間明宏 厂060-8638 札幌市北区北15条西7丁目 北海道大学大学院医学研究科耳鼻咽喉科・頭頸部外科 